\title{
ANALISIS KEMAMPUAN KONEKSI MATEMATIK DAN KEPERCAYAAN DIRI SISWA SMP
}

\author{
Dian Andriani ${ }^{1}$, Usman Aripin ${ }^{2}$ \\ 1,2 IKIP Siliwangi, Jln Terusan Jenderal Sudirman. Cimahi \\ Iandrianihaziq@gmail.com, ${ }^{2}$ usman.aripin@ikipsiliwangi.ac.id
}

\begin{abstract}
The purpose of this study was to determine the mathematical connection skills and confidence of junior high school students. With the background of mathematical connection skills and low selfconfidence of students, this study was conducted. The method used for analysis in this study is Descriptive Qualitative Methods in order to analyze the results of students 'work on the questions of students' mathematical connection skills and self-confidence inquiry questionnaires in Bina Harapan Bangsa Middle School students. The subjects studied were 1 class of students, amounting to 37 students in class IX-B of Bina Harapan Bangsa Middle School in Bandung Regency. The test questions used are mathematical connections with the number of questions, there are 3 questions and non-test instruments for students' self-confidence. The results of the analysis obtained are the mathematical connection ability of students in junior high schools in the district of Bandung based on written description tests are still relatively low. But students already have sufficient self-confidence in learning mathematics.
\end{abstract}

Keywords: Mathematical Connection Ability, Self Confidence

\begin{abstract}
Abstrak
Tujuan dari penelitian ini untuk menganalisis kemampuan koneksi matematik dan kepercayaan diri siswa smp. Metode yang dipakai untuk analisis pada penelitian ini ialah Metode Kualitatif Deskriptif agar dapat menganalisis hasil pengerjaan siswa terhadap pertanyaan-pertanyaan kemampuan koneksi matematik siswa dan angket penelusuran kepercayaan diri siswa SMP Bina Harapan Bangsa. Subjek yang diteliti adalah 1 kelas siswa yang berjumlah 37 siswa kelas IX-B SMP Bina Harapan Bangsa di daerah Kabupaten Bandung. Adapun soal tes yang dipakai adalah koneksi matematik dengan banyaknya soal ada 3 pertanyaan serta instrumen non tes kepercayaan diri siswa. Hasil analisis yang didapat ialah kemampuan koneksi matematik siswa di SMP di daerah kabupaten Bandung berdasarkan tes uraian tertulis masih tergolong cukup rendah. Namun siswa sudah memiliki kepercayaan diri yang cukup baik dalam pembelajaran matematika.
\end{abstract}

Kata Kunci: Kemampuan Koneksi Matematik, Kepercayaan Diri

How to cite: Andriani, D., Aripin, U. (2019). Analisis Kemampuan Koneksi Matematik dan Kepercayaan Diri Siswa SMP. JPMI - Jurnal Pembelajaran Matematika Inovatif, 2 (1), 25-32.

\section{PENDAHULUAN}

Dalam setiap bidang kehidupan matematika adalah salah satu ilmu yang selalu digunakan untuk menyelesaikan berbagai permasalahan yang terjadi. Sehingga matematika merupakan ilmu yang sanngat penting untuk dipelajari dan dipahami. Menurut Bruner (Hadin, Pauji2, \& Arifin, 2018) menyatakan bahwa setiap konsep pada matematika memiliki keterkaitan dengan konsep lain. Dimana untuk bisa menyelesaikan masalah matematika yang berhubungan dengan konsep di luar matematika siswa harus memiliki kemampuan koneksi matematik. 
Kemudian peneliti melakukan penelitian di salah satu sekolah yang berada di daerah Bandung. Secara keseluruhan dalam pelaksanaan pembelajaran berjalan dengan lancar dan baik. Antusias siswa dalam kegiatan belajar yang disampaikan peneliti cukup baik. Walau terkadang masih ada kekurangan yang terjadi, misalnya pengelolaan kelas yang masih kurang dapat dikondisikan. Namun itu semua merupakan proses dalam pembelajaran agar lebih baik lagi.

Dalam pelaksanaan mengajar peneliti melihat adanya kekurangan siswa dalam menghubungkan konsep matematika dengan permasalahan yang terjadi dalam kehidupan nyata. Bahkan banyak sekali masalah yang dalam pengerjaannya menggunakan konsep statistika khususnya dan matematika pada umumnya. Siswa harus menguasai konsep matematika untuk dipergunakan dalam ilmu lain dan dalam menyelesaikan berbagai permasalahan nyata (Ulya, Irawati, \& Maulana, 2016). Untuk dapat mengaitkan konsep matematika dengan berbagai ilmu lain dan dapat menyelesaikan masalah nyata dengan konsep matematika siswa harus memiliki kemampuan koneksi matematik.

Oleh karena itu dalam pembelajaran khususnya matematika perlu diterapkan strategi atau metode pembelajaran yang dikaitkan dengan kemampuan koneksi matematik siswa. Kemampuan koneksi matematik merupakan suatu keterampialan yang harus dibangun, karena dengan kemampuan koneksi matematik yang bagus akan membantu siswa dalam mengetahui hubungan antar konsep dalam matematika maupun diluar matematika (Hadin, Pauji, \& Arifin, 2018). Dan lebih baik lagi jika kemampuan tersebut ditekankan lagi di sekolah. Sesuai dengan pendapat NCTM, 1989 yang merumuskan bahwa koneksi matematik atau mathematical connections harus lebih ditekankan lagi di sekolah-sekolah karena merupakan hal penting dalam pembelajaran(Anita, 2014).

Dalam Hendriana, Rohaeti, Sumarmo, (2017) indikator koneksi matematik adalah sebagai berikut:

a. mencari hubungan antar berbagai representasi konsep dan prosedur;

b. Mencari koneksi satu prosedur ke prosedur lain dalam representasi yang ekuivalen, ,;

c. Mencari hubungan berbagai representasi konsep dan prosedur;

d. Menggunakan matematika dalam kehidupan nyata atau bidang studi lain;

e. Menggunakan dan menilai keterkaitan antar topik matematika dan topik lain.

Selain kemampuan kognitif dibutuhkan juga kemampuan afektif agar tujuan dalam pembelajaran bisa tercapai. Kemampuan diri lain yang dibutuhkan yaitu kepercayaan diri. Kepercayaan diri sangatlah dibutuhkan oleh siswa agar mampu mengoptimalkan kemampuan dirinya (Novtiar \& Aripin, 2017).

Kepercayaan diri merupakan sikap yang sangat perlu dimiliki oleh setiap siswa. Karena dengan kepercayaan diri siswa akan mudah mengungkapkan gagasan dalam pikirannya dalam menyelesaikan masalah-masalah matematika. Menurut Rachmat, 2000 (Hendriana, 2012) Kepercayaan diri artinya sebagai suatu kepercayaan terhadap kemampuan sendiri yang sudah dimiliki setiap orang dalam dirinya, serta bagaimana mereka melihat dirinya dengan merujuk pada konsep diri.

Siswa dengan kepercayaan diri tinggi akan lebih mampu mencapai keberhasilan pada dirinya. Percaya terhadap kemampuan diri ini akan mempengaruhi kinerja (Hendriana, 2012). Siswa yang kepercayaan dirinya kurang akan menghambat dalam mencapai prestasinya. Dengan kepercayaan diri yang tinggi siswa akan memiliki semangat yang tinggi dalam menyelesaikan 
apa yang menjadi sasaran dalam tugasnya. Tanpa rasa percaya diri dalam menyelesaikan suatu soal siswa tersebut akan memperoleh hasil yang tidak maksimal (Muhamad, 2017).

Maka dari itu perlu dilaksanakan penelitian untuk menganalisis kemampuan koneksi matematik dan kepercayaan diri siswa smp pada materi statistika. Tujuannya adalah menganalis kemampuan koneksi matematik dan kepercayaan diri siswa SMP pada materi statistika.

\section{METODE}

Metode yang digunakan deskriptif kualitatif. Yang menjadi subjeknya yaitu siswa kelas IX-B semester I d SMP Bina Harapan Bangsa tahun ajaran 2018/2019 yang berjumlah 37 orang. Tes yang dilakukan yaitu tes kemampuan koneksi matematik siswa yang terdiri dari tiga pertanyaan yang mewakili tiga indicator dengan masing-masing skor maksimal dan skala kepercayaan diri dengan indikator kepercayaan diri siswa menurut Skala kemampuan diri bertujuan agar mengetahui skala kepercayaan diri siswa terhadap matematika.

Teknik menganalisis yang dilakukan terdiri dari menilai jawaban siswa berdasarkan tes yang diberikan, menentukan jenis-jenis kesalahan dalam menjawab oleh siswa dan mengetahui banyaknya jenis kesalahan siswa digunakan suatu rumus presentase berikut.

$$
\mathrm{P}=\frac{n}{N} \times 100
$$

Keterangan:

$\mathrm{P}=$ Presentase terhadap kesalahan hasil siswa

$\mathrm{n}=$ jumlah siswa yang mengalami kesulitan

$\mathrm{N}=$ Banyaknya siswa yang mengikuti tes

Kriteria presentase banyaknya kesalahan yang diambil dari masing-masing jenis kesalahan, konversi skor merujuk dari Nurkanca \& Sunarta (Nurdwiandari, 2018)

Tabel 1. Kriteria Presentasi Banyaknya Kesalahan

\begin{tabular}{cc}
\hline Presentase $(\mathrm{P})$ & Kriteria \\
\hline $90,00 \leq \mathrm{P} \leq 100$ & Sangat Tinggi \\
$80,00 \leq \mathrm{P} \leq 90,00$ & Tinggi \\
$65,00 \leq \mathrm{P} \leq 80,00$ & Sedang \\
$55,00 \leq \mathrm{P} \leq 65,00$ & Rendah \\
$\mathrm{P}<55,00$ & Sangat Rendah \\
\hline
\end{tabular}

\section{HASIL}

\section{Hasil Analisis Kemampuan Koneksi Matematik}

Kemudian dilakukan analisis pada data hasil dari jawaban siswa untuk memperoleh suatu gambaran kemampuan koneksi matematik siswa. Dari 37 siswa yang melakukan tes diperoleh persentase jawaban siswa. 
Tabel 2. Persentase (P) Banyaknya Kesalahan Jawaban

\begin{tabular}{lccc}
\hline Indikator & P Benar & P Salah & Kriteria Kesalahan \\
& & & \\
\hline $\begin{array}{l}\text { Memahami hubungan antar } \\
\text { topik matematika }\end{array}$ & 37,84 & 62,16 & rendah \\
$\begin{array}{l}\text { Mencari representasi ekuivalen } \\
\text { dari konsep dan prosedur yang }\end{array}$ & 32,44 & 67,56 & sedang \\
$\begin{array}{l}\text { sama } \\
\text { menggunakan matematika dalam } \\
\text { bidang studi lain atau kehidupan } \\
\text { sehari-hari. }\end{array}$ & 16,22 & 83,78 & tinggi \\
\hline
\end{tabular}

Berdasarkan tabel 2. terlihat tingkat kesalahan siswa pada indikator mengenali berbagai cara dari konsep yang sama tergolong rendah. Siswa yang menjawab benar 37,82\% artinya sebanyak $37,82 \%$ siswa mampu dalam indicator tersebut, sedangkan $62,16 \%$ siswa belum mampu mengenali cara penyelesaian lain dari konsep yang sama. Kesalahan siswa pada indikator kedua tergolong sedang. Sebanyak 67,56\% siswa belum mampu menilai dan menggunakan hubungan antar tema dan keterkaitan di luar matematika, dan 32,44\% siswa sudah mampu pada indicator tersebut. Dan menggunakan matematika dalam kehidupan nyata tergolong tinggi. Sebanyak 16,22\% siswa mampu menggunakan matematika dalam kehidupan sehari-hari, dan sebanyak $83,78 \%$ siswa belum mampu menyelesaikan masalah sehari-hari dengan konsep matematika.

Tabel 3. Skor Kemampuan Koneksi Matematik Siswa

\begin{tabular}{ccc} 
Skor & Banyak siswa & Keterangan \\
\hline 12 & 0 & Sangat Baik \\
9 & 15 & Baik \\
6 & 20 & Cukup \\
3 & 2 & Tidak Baik \\
0 & 0 & Sangat tidak baik \\
\hline
\end{tabular}

Berdasarkan tabel tersebut tidak ada yang kemampuan koneksi matematiknya sangat baik. Siswa yang kemampuannya baik ada 15 orang. Siswa yang kemampuannya baik yaitu siswa yang mampu menyelesaikan soal tapi belum lengkap atau masih ada sedikit kesalahan. Ada 20 siswa yang kemampuan koneksinya cukup, yang artinya siswa masih melakukan kesalahan yang tidak sedikit dalam menyelesaikan soal. Masih ada 2 orang siswa yang kemampuannya tidak baik. Siswa yang tidak baik siswa belum mampu menyelesaikan soal kemampuan koneksi matematik.

\section{Analisis Kesalahan pada Jawaban Siswa}

Berikut ini pembahasan jawaban pada siswa yang mendapatkan skor 2 pada setiap pertanyaan kemampuan tes koneksi matematik. Berikut adalah pertanyaan pada kemampuan tes koneksi serta analisis-analisisnya.

Analisis Jawaban pada Siswa yang Memperoleh nilai Skor 2 pada pertanyaan nomor 1 Perhatikan tabel 4. berikut ini

\begin{tabular}{|l|l|l|l|l|l|l|}
\hline Nilai & 5 & 6 & 7 & 8 & 9 & 10 \\
\hline Frekuensi & 5 & 10 & $\mathrm{X}$ & 5 & 2 & 0 \\
\hline
\end{tabular}


Jika data di atas memiliki nilai rata-rata 6,56. Banyak siswa yang mendapat nilai 7adalah....

Berdasarkan pertanyaan tersebut diperoleh berbagai jawaban siswa. Berikut ini dapat disajikan salah satu jawaban yang memperoleh skor 2.

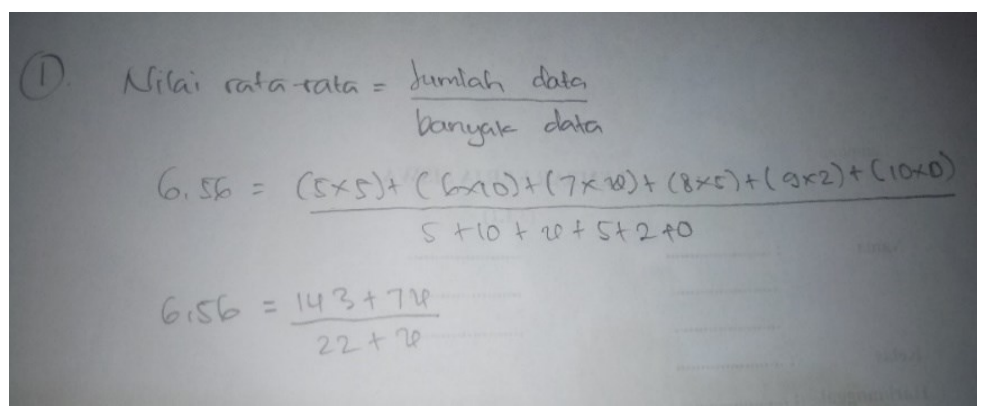

Gambar 1. Jawaban Siswa No.1

Gambar 1 menunjukan bahwa siswa sudah berusaha memahami pertanyaan tersebut. Siswa mencoba menyelesaikan permasalahan yang terdapat didalam soal tersebut dengan hal kemampuan yang dia miliki. Namun siswa belum bisa menyelesaikannya dengan lengkap. Sehingga siswa memperoleh nilai 2.

\section{Analisis Jawaban Siswa yang Memperoleh nilai Skor 2 pada pertanyaan nomor 2}

Berdasarkan pendataan tinggi badan seluruh siswa kelas IX, $150 \mathrm{~cm}$ sebanyak tiga orang, 151 $\mathrm{cm}$ sebanyak tujuh orang, $153 \mathrm{~cm}$ sebanyak sebelas orang, $155 \mathrm{~cm}$ sebnayak delapan orang, $157 \mathrm{~cm}$ sebanyak tujuh orang, dan $160 \mathrm{~cm}$ siswa sebanyak lima orang. Tentukan rata-rata tinggi badan siswa tersebut dengan beberapa cara (repsresentasi).

Berdasarkan pertanyaan tersebut diperoleh berbagai jawaban siswa. Berikut ini dapat disajikan salah satu jawaban siswa.

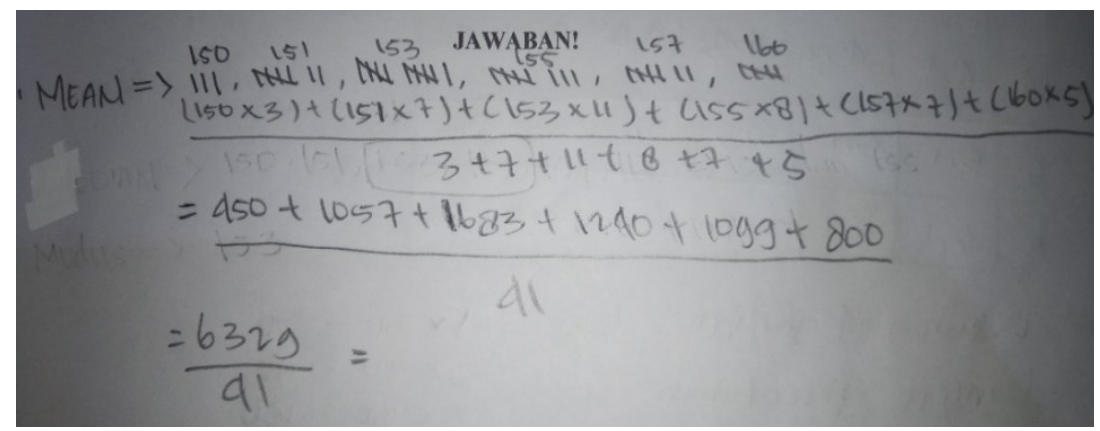

Gambar 2. Jawaban Siswa No.2

Gambar 2 memperlihatkan bahwa hasil siswa sudah hampir benar, namun belum bisa diselesaikan dengan lengkap. Dan hanya menyelesaikan dengan satu cara. Sehingga siswa memperoleh nilai 2 .

\section{Analisis Jawaban pada Siswa yang Perolehan Skornya 2 pada pertanyaan nomor 3}

Hasil pendataan berat badan 40 orang siswa kelas VII adalah tujuh siswa beratnya $33 \mathrm{~kg}$, lima siswa beratnya $35 \mathrm{~kg}$, tiga orang siswa beratnya $37 \mathrm{~kg}$, sepuluh siswa beratnya $39 \mathrm{~kg}$, dua 
belas siswa beratnya $41 \mathrm{~kg}$, tujuh orang siswa beratnya 43 , dan tiga orang siswa beratnya 45 $\mathrm{kg}$.

a. Sajikan ke dalam bentuk tabel distribusi frekuensi data tunggal

b. Buatlah histogram data tunggal

c. Tuliskan nama mata pelajaran selain matematika yang berkaitan dengan pengukuran berat badan. Jelaskan.

Berdasarkan pertanyaan tersebut diperoleh berbagai jawaban siswa. Dapat disajikan jawaban dengan skor 2.

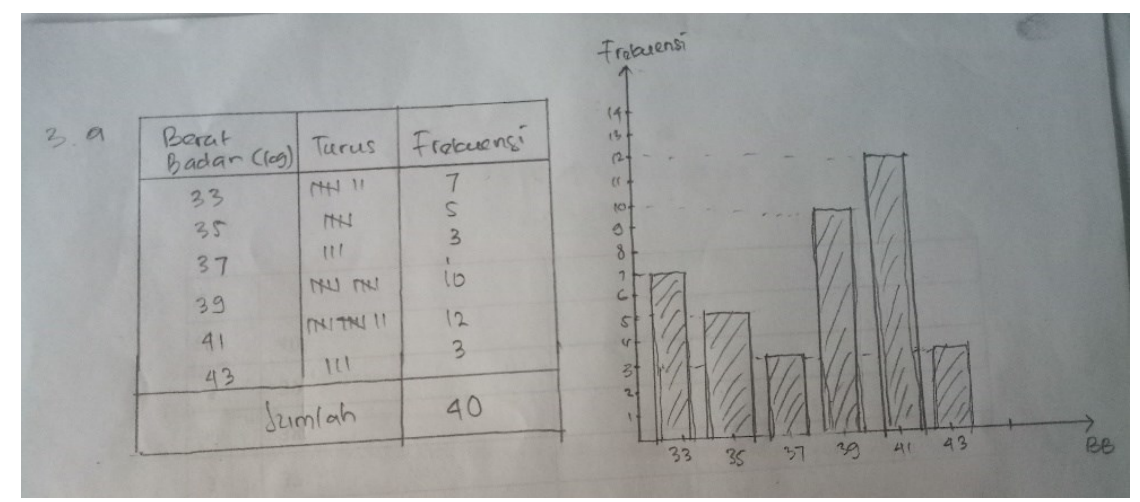

Gambar 3. Jawaban Siswa No.3

Gambar 2 memperlihatkan bahwa pada poin a sudah bisa menyelesaikan dengan benar, pada poin $b$ siswa mencoba menjawab sesuai dengan pemahamannya walau hasilnya masih keliru. Untuk poin tiga siswa belum dapat menyelesaikan pertanyaan yang diberikan.

\section{Hasil Kepercayaan Diri Matematik Siswa}

Analisis disesuaikan dengan indikator dari kepercayaan diri. Indikatornya (Hendriana et al.,2017) sebagai berikut: 1) Percaya kepada kemampuan sendiri; 2)Bertindak mandiri ketika mengambil keputusan; 3) Memiliki persepsi diri yang positif; 4) Berani mengutarakan pendapat.

Pada Tabel 5 merupakan persentase dari 37 siswa dalam pembelajaran matematika

Tabel 5. persentase kepercayaan diri siswa

\begin{tabular}{llll}
\hline No & Indikator & Setuju & Tidak setuju \\
\hline 1 & Percaya kepada kemampuan sendiri & 50,50 & 49,5 \\
2 & Bertindak mandiri ketika mengambil keputusan & 54,50 & 45,5 \\
3 & Memiliki persepsi diri yang positif & 53,9 & 46,1 \\
4 & Berani mengungkapkan pendapat & 58 & 42 \\
\hline
\end{tabular}

Berdasarkan tabel secara keseluruhan lebih dari 50\% siswa setuju terhadap indikator-indikator kepercayaan diri siswa. Yang artinya banyak dari siswa (54,23\%) sudah memiliki kepercayaan diri yang cukup baik terhadap pembelajaran matematika. Sejalan dengan (Hendriana, 2012) siswa dengan kepercayaan diri yang tinggi akan dapat mempelajari setiap materi matematika sesulit apapun. Kepercayaan diri yang positif akan menambah 
semangat dan kemampuan berpikir untuk merasa yakin dengan kompetensi yang telah dimiliki, hal ini akan mendorong seseorang untuk berusaha semaksimal mungkin sesuai dengan tujuan yang akan dicapai yaitu meraih prestasi belajar yang baik (Eviliasani, Hendriana, \& Senjayawati, 2018).

\section{Pembahasan}

Kemampuan koneksi matematik siswa pada indikator mengenali berbagai cara dari konsep yang sama ada lebih dari seperempat siswa. Dan sisanya belum mampu mengenali indicator tersebut. Ini diakibatkan karena siswa belum mampu mengidentifikasi konsep yang ekuivalen dari konsep yang sama. Lalu untuk indikator menggunakan dan menilai keterkaitan antar topik matematika dan keterkaitan di luar matematika lebih dari seperempat siswa, namun lebih sedikit dari indikator sebelumnya, dan sebagian belum mampu menilai dan menggunakan hubungan antar topik di luar matematika dan keterkaitan antar topik matematika. Disebabkan oleh kurangnya kemampuan siswa mengaitkan konsep matematika dengan konsep lain. Kemudian pada indikator menggunakan matematika dalam kehidupan sehari-hari siswa yang dapat mengerjakan soal kurang dari seperempat banyaknya siswa. Hal tersebut karena siswa belum mampu mengaplikasikan konsep matematika ke dalam permasalahan pada kehidupan sehari-hari. Berdasarkan hasil tes dari siswa menunjukan bahwa kemampuan koneksi matematik siswa kelas IX-B SMP Bina Harapan Bangsa masih kurang baik. Sehingga diperlukan pembiasaan yang memotivasi siswa untuk mengerjakan dan menyelesaikan soal-soal koneksi untuk melatih kemampuan mereka. Menurut Maulana, Irawati, Ulya (2016) Yakni siswa harus mampu mengaplikasikan matematika dalam berbagai bidang, bukan hanya dalam matematika tapi dalam pelajaran lain dan dalam kehudupannya.

Untuk afektifnya secara keseluruhan lebih dari 50\% siswa sudah memiliki kepercayaan diri yang cukup baik terhadap matematika, mereka merasa mampu melaksanakan pembelajaran matematika. Sehingga meskipun kemampuan koneksi matematik siswa masih kurang, masih bisa dikembangkan lagi.

\section{KESIMPULAN}

Analisis terhadap kemampuan koneksi matematik siswa dapat disimpulkan bahwa kesalahan siswa yang paling banyak dilakukan terjadi pada indikator menggunakan matematika dalam kehidupan nyata atau ilmu lain di luar matematika.

Kesimpulan untuk kepercayaan diri siswa bahwa sebagian besar siswa sudah memiliki kepercayaan diri yang baik terhadap pembelajaran matematika.

\section{UCAPAN TERIMA KASIH}

Kami ucapkan terimakasih kepada pihak yang telah banyak memberikan bantuan hingga dapat tersusunnya laporan hasil penelitian ini. Kepada pimpinan IKIP Siliwangi, dosen pembimbing, serta pihak SMP Bina Harapan Bangsa yang telah memberikan kesempatan dan fasilitas kepada peneliti selama melakukan penelitian.

\section{DAFTAR PUSTAKA}

Anita, I. . (2014). Pengaruh Kecemasan Matematika (Mathematics Anxiety) terhadap Kemampuan Koneksi Matematis Siswa SMP. Infinity, 3(1), 125-132. https://doi.org/http://dx.doi.org/10.22460/infinity.v3i1.43 
Hendriana, H., Rohaeti,E.E., Sumarmo, U. (2017). Hard Skills dan Soft Skills Matematika Siswa. Bandung: PT. Rafika Aditama.

Muhamad, N. (2017). Pengaruh Metode Discovery Learning Untuk Meningkatkan Representasi Matematis Dan Percaya Diri Siswa. Jurnal Pendidikan, 9(1), 75-90. https://doi.org/10.1021/la303940a

Novtiar, C., \& Aripin, U. (2017). Meningkatkan Kemampuan Berpikir Kritis Matematis dan Kepercayaan Diri Siswa SMP Melalui Pendekatan Open Ended. Prisma, 6(2), 119-131.

Nurdwiandari, P. (2018). Analisis kemampuan berpikir kritis matematik dan kemampuan diri siswa smp di kabupaten bandung barat, 1(5), 1005-1014.

Ulya, I. F., Irawati, R., \& Maulana. (2016). Peningkatan Kemampuan Koneksi Matematis Dan Motivasi Belajar Siswa Menggunakan Pendekatan Kontekstual. Jurnal Pena Ilmiah, $1(1), 121-130$.

Eviliasani, K., Hendriana, H., \& Senjayawati, E. (2018). Analisis kemampuan berpikir kreatif matematis ditinjau dari kepercayaan diri siswa smp kelas viii di kota cimahi pada materi bangun datar segi empat, 1(3), 333-346. https://doi.org/10.22460/jpmi.v1i3.333-346

Hadin, Pauji2, H. M., \& Arifin, U. (2018). Analisis Kemampuan Koneksi Matematik Siswa MTs Ditinjau dari Self Regulated Learning. Jurnal JPPM, 11(1), 657-666. https://doi.org/10.1007/978-3-8274-2352-8_21

Hendriana, H. (2012). Pembelajaran Matematika Humanis Dengan Metaphorical Thinking Untuk Meningkatkan Kepercayaan Diri Siswa. Jurnal Infinity, 1(1), 90-103. https://doi.org/10.1016/j.molimm.2007.05.017 